\title{
A Novel Heparin-dependent Processing Pathway for Human Tryptase Autocatalysis Followed by Activation with Dipeptidyl Peptidase I
}

\author{
Kentaro Sakai, Shunlin Ren, and Lawrence B. Schwartz \\ The Division of Rheumatology, Allergy and Immunology, Department of Medicine, Virginia Commonwealth University, Richmond, \\ Virginia 23298
}

\begin{abstract}
Tryptase is the major protein constituent of human mast cells, where it is stored within the secretory granules as a fully active tetramer. Two tryptase genes ( $\alpha$ and $\beta$ ) are expressed by human mast cells at the level of mRNA and protein, each with a 30 amino acid leader sequence. Recombinant precursor forms of human $\alpha$ - and $\beta$-tryptase were produced in a baculovirus system, purified, and used to study their processing. Monomeric $\beta$-protryptase first is shown to be intermolecularly autoprocessed to monomeric $\beta$-pro'tryptase at acid $\mathrm{pH}$ in the presence of heparin by cleavage between $\mathrm{Arg}^{-3}$ and $\mathrm{Val}^{-2}$ in the leader peptide. The precursor of $\alpha$-tryptase has an $\mathrm{Arg}^{-3}$ to $\mathrm{Gln}^{-3}$ mutation that precludes autoprocessing. This may explain why $\alpha$-tryptase is not stored in secretory granules, but instead is constitutively secreted by mast cells and is the predominant form of tryptase found in blood in both healthy subjects and those with systemic mastocytosis under nonacute conditions. Second, the $\mathrm{NH}_{2}$-terminal activation dipeptide on $\beta$-pro'tryptase is removed by dipeptidyl peptidase I at acid $\mathrm{pH}$ in the absence of heparin to yield an inactive monomeric form of tryptase. Conversion of the catalytic portion of $\beta$-tryptase to the active homotetramer at acid $\mathrm{pH}$ requires heparin. Thus, $\beta$-tryptase homotetramers probably account for active enzyme detected in vivo. Also, processing of tryptase to an active form should occur optimally only in cells that coexpress heparin proteoglycan, restricting this pathway to a mast cell lineage. (J. Clin. Invest. 1996. 97: 988-995.) Key words: mast cells • protease • anaphylaxis • mastocytosis $\bullet$ baculovirus
\end{abstract}

\section{Introduction}

Tryptase, a neutral serine protease, is the most abundant protein component of human mast cells, where it is selectively stored with full enzymatic activity in the secretory granules of all types of human mast cells, the major effector cell of allergic reactions (1). When activated mast cells degranulate, they release histamine and tryptase in parallel (2). Because tryptase persists in the circulation far longer than histamine, it has been

Address correspondence to Dr. Lawrence B. Schwartz, Division of Rheumatology, Allergy and Immunology, Department of Medicine, Virginia Commonwealth University, P.O. Box 980263, Richmond, VA 23298. Phone: 804-828-9658; FAX: 804-828-0283.

Received for publication 28 September 1995 and accepted in revised form 13 November 1995.

J. Clin. Invest.

(C) The American Society for Clinical Investigation, Inc.

0021-9738/96/02/0988/08 \$2.00

Volume 97, Number 4, February 1996, 988-995 used as a precise clinical marker of mast cell activation in diseases such as systemic anaphylaxis and asthma (3). Because of its potential to stimulate smooth muscle, fibroblasts, and tissue turnover (4), tryptase enzymatic activity has become a therapeutic target in asthma, where a putative inhibitor of this enzyme appears to show efficacy in a sheep model of human asthma (5).

In humans, one $\alpha$-tryptase gene and at least one $\beta$-tryptase gene reside in the normal haploid genome on chromosome 16 (6-8). mRNAs corresponding to both $\alpha$ - and $\beta$-tryptase encode proteins that are $92 \%$ identical and are found in almost all preparations of mast cells dispersed from human lung and skin (9). Using immunoassays that distinguish recombinant hu$\operatorname{man}(\mathrm{rh})^{1} \alpha$ - and $\beta$-tryptase from one another, $\alpha$-tryptase is the predominant form of tryptase detected in normal serum and is markedly elevated in patients with systemic mastocytosis, whereas $\beta$-tryptase is the major form elevated in serum during systemic anaphylaxis (10). A molecular explanation for the apparent constitutive secretion of $\alpha$-tryptase, and secretory granule storage of $\beta$-tryptase, as yet, is lacking.

Like other serine proteases in secretory granules of hematopoietic cells (chymase, mast cell carboxypeptidase A, cathepsin G, granzymes, and elastase) (11), tryptase is synthesized as a precursor that must be converted into its mature form by intracellular proteolysis. Proforms of chymase and cathepsin $\mathrm{G}$, like most of the granzymes, each have an $\mathrm{NH}_{2}-$ terminal activation dipeptide with an acidic residue at position -1 that is removed by dipeptidyl peptidase I (DPPI), a cysteine protease with an acid $\mathrm{pH}$ optimum localized to the secretory granules of bone marrow-derived cells (12). In contrast, protryptase has been predicted to contain 12, 10, and 10 amino acid activation peptides for human, murine, and canine forms, respectively $(6-8,13,14)$, each beginning with Ala-Pro, a stop sequence for DPPI. For human chymase, $\mathrm{Glu}^{-1}$ is critical for the heparin-specific activation by DPPI (15), but each tryptase precursor contains a $\mathrm{Gly}^{-1}$. Involvement of DPPI in the processing of murine tryptase studied pharmacologically in cultures of murine mast cells is controversial $(12,16)$. Also, unlike the monomeric chymases and cathepsin G, enzymatically active tryptase is a tetramer. Heparin binds to and stabilizes the enzymatically active form of human tryptase (17), but surprisingly does neither to rat tryptase (18), even though both molecules colocalize to rat mast cell secretory granules. Mouse mast cell protease 7 , another tryptase, by protein modeling, is predicted to bind to heparin through clustered His residues at acidic but not at neutral $\mathrm{pH}$, this prediction being supported experimentally with recombinant mouse mast cell protease 7

1. Abbreviations used in this paper: DFP, diisopropyl fluorophosphate; DPPI, dipeptidyl peptidase I; rh, recombinant human; SBTI, soybean trypsin inhibitor; TGPL, tosyl-L-glycine-L-lysine- $p$-nitroanilide; TPCK, $N$-tosyl-phenylalanine-chloromethyl ketone. 
precursor protein (19). Thus, tryptase may have unique heparin-dependent activation requirements.

For the current study rh $\alpha$ - and $r h \beta$-tryptase cDNAs encoding the entire 30 amino acid leader peptides and 245 amino acid catalytic portions of each were expressed in a baculovirus/ insect cell system, and immunoaffinity purified with the B2 $\mathrm{mAb}(20)$. The Ala ${ }^{-12}$ to $\mathrm{Gly}^{-1}$ portions of the leader peptides remained in these enzymatically inactive tryptase precursors, referred to as protryptases, which were $\mathrm{N}$-glycosylated on 0,1 , or 2 of the two putative sites on $\alpha$-tryptase and on 0 or 1 of the single putative site on $\beta$-tryptase. The current study shows that the $\beta$-protryptase is processed from an inactive monomer to a fully active tetramer at acid $\mathrm{pH}$ in the presence of heparin by an autocatalytic cleavage at $\mathrm{Arg}^{-3} / \mathrm{Val}^{-2}$ and removal of the dipeptide by DPPI, whereas $\alpha$-protryptase cannot undergo the autoprocessing step and therefore remains an inactive precursor.

\section{Methods}

Materials. Mes, 5-bromo-4-chloro-3-indoyl phosphate/nitroblue tetrazolium-buffered substrate tablet, 2-mercaptoethanol, alkaline phosphatase-conjugated goat IgG anti-mouse IgG (Fcy specific), TCA, dextran sulfate (500,000 D), acetone, glycerol, glycine, ethylene glycol, pepstatin A, cysteine, E-64, iodoacetamide, EDTA, EGTA, 1,10-o-phenanthroline, soybean trypsin inhibitor (SBTI), $N$-tosylphenylalanine-chloromethyl ketone (TPCK), aprotinin, diisopropyl fluorophosphate (DFP), 3,4-dichloroisocoumarin, PMSF, BSA, blue dextran $(2,000,000 \mathrm{D})$, catalase, ovalbumin, apoferritin, thyroglobulin, aldolase, and chymotrypsinogen, bromophenol blue (Sigma Chemical Co., St. Louis, MO); $N$-glycosidase F, $O$-glycosidase, tosylglycine-L-proline-L-lysine- $p$-nitroanilide (TGPL); bovine DPPI (Boehringer Mannheim Biochemicals, Indianapolis, IN); Coomassie brilliant blue R-250 (Pharmacia LKB Biotechnology AB, Uppsala, Sweden); prestained protein molecular weight standards, HBSS and heparin-agarose ALD (Gibco BRL Life Technologies, Inc., Grand Island, NY); SDS (Bio-Rad Laboratories, Inc., Hercules, CA); and Centricon-10 (Amicon, Inc., Beverly, MA) were obtained as indicated. Antitryptase $\mathrm{mAb}, \mathrm{G} 3$, was prepared and purified as previously described (21). The human mast cell leukemia cell line, HMC-1, was a gift from Dr. G. Gleich and Dr. J. Butterfield (Mayo Clinic, Rochester, MN) (22). The human basophil leukemia cell line, KU812, was obtained from Dr. G. Nilsson (University of Uppsala, Uppsala, Sweden) (23). The human monocytic leukemia cell line, MonoMac-6, was supplied by Dr. H. W. Ziegler-Heitbrock (University of Munich, Munich, Germany) (24). The mouse 3T3 fibroblast cell line was obtained from American Type Tissue Culture (Rockville, MD). Heparin proteoglycan $(\sim 750,000 \mathrm{D})$ from rat peritoneal mast cells (25) and porcine heparin glycosaminoglycan (1,200-20,000 D) (Sigma Chemical Co.) (26) were prepared as described. Gly-Phe- $\mathrm{CHN}_{2}$, a DPPI-specific inhibitor, was prepared as described (16) and kindly provided by Dr. W. Serafin (Vanderbilt University, Nashville, TN). Native tryptase from human skin was purified as described previously by sequential affinity chromatographies on $\mathrm{B} 2 \mathrm{mAb}$ affi-gel and heparin-agarose ALD (27). Rh $\alpha$-protryptase and $\operatorname{rh} \beta$-protryptase were expressed in a baculovirus/insect cells system and were immunopurified by $\mathrm{B} 2 \mathrm{mAb}$ affi-gel as described (20).

Activation of rh $\alpha$-protryptase and rh $\beta$-protryptase by cell extracts. HMC-1, Mono-Mac-6, KU-812, and mouse 3T3 fibroblast cells, $10^{7}$ each, were washed three times with $1.5 \mathrm{ml}$ of HBSS, sonicated ( 8 pulses, $50 \%$ pulse cycle, 4 power, microtip attachment, Sonicator $^{\mathrm{TM}}$ cell Disruptor Model W-225R; Heat System-Ultrasonics. Inc., Planview, NY) on ice with $0.5 \mathrm{ml}$ of $10 \mathrm{mM} \mathrm{Mes,} \mathrm{pH} 6.5$, containing $0.1 \mathrm{M} \mathrm{NaCl}$ and centrifuged at $12,000 \mathrm{~g}$ for $5 \mathrm{~min}$ at $4^{\circ} \mathrm{C}$ to remove cell debris. The supernatants were diluted with the same buffer to adjust the protein concentration to $0.5 \mathrm{mg} / \mathrm{ml}$ and stored at $-75^{\circ} \mathrm{C}$.

$\mathrm{Rh} \alpha$-protryptase or $\mathrm{rh} \beta$-protryptase (500 $\mathrm{ng}$ ) was incubated in
$100 \mu \mathrm{l}$ of $0.1 \mathrm{M} \mathrm{Mes,} \mathrm{pH} 6.5$, containing $0.1 \mathrm{M} \mathrm{NaCl}, 0.3 \mathrm{mg} / \mathrm{ml}$ of various cell extracts, $0.1 \mathrm{mg} / \mathrm{ml}$ of dextran sulfate and $0.5 \mathrm{mg} / \mathrm{ml}$ of BSA at $37^{\circ} \mathrm{C}$ for the times indicated. In some experiments, heparin proteoglycan, heparin glycosaminoglycan, chondroitin sulfate A, chondroitin sulfate $B$, chondroitin sulfate $C$, or chondroitin sulfate $E$ was substituted for dextran sulfate. One portion of each sample removed from the incubation mixtures was assessed for tryptase enzyme activity based on TGPL hydrolysis, and another portion denatured by adding an equal volume of $5 \mathrm{mM}$ Tris, $\mathrm{pH} 8.3$, buffer containing $2 \%$ (wt/vol) SDS, $10 \%$ (vol/vol) 2-mercaptoethanol, $10 \%$ (vol/vol) glycerol, $38 \mathrm{mM}$ glycine, and $0.2 \%$ (wt/vol) bromophenol blue $(2 \times$ SDSPAGE loading buffer). The preparations were boiled for $5 \mathrm{~min}$ and were subjected to electrophoresis and Western blotting. For the effects of protease inhibitors on activation of $\operatorname{rh} \beta$-protryptase by cell extracts, each protease inhibitor at the concentration described in the text was incubated with $500 \mathrm{ng}$ of $\mathrm{rh} \beta$-protryptase for $2 \mathrm{~h}$ at $37^{\circ} \mathrm{C}$ as above, except that each cell extract was preincubated with the inhibitor for $15 \mathrm{~min}$ at room temperature. $\mathrm{pH}$ profiles of activation of $\mathrm{rh} \beta$ protryptase by cell extracts were determined in $0.1 \mathrm{M}$ acetate $(\mathrm{pH}$ 4.0-6.0), 0.1 M Mes (pH 6.0-7.0) and 0.1 M Tris-HCl (pH 7.0-9.0) buffers containing $0.1 \mathrm{M} \mathrm{NaCl}, 0.3 \mathrm{mg}$ protein/ml of cell extracts, 0.1 $\mathrm{mg} / \mathrm{ml}$ of dextran sulfate, and $0.5 \mathrm{mg} / \mathrm{ml}$ of BSA at $37^{\circ} \mathrm{C}$ for $2 \mathrm{~h}$.

Autocatalytic processing of rh $\beta$-protryptase to rh $\beta$-pro'tryptase. $\mathrm{Rh} \beta$-protryptase $(0.125-1.25 \mu \mathrm{g})$ was incubated in $100 \mu \mathrm{l}$ of $50 \mathrm{mM}$ acetate, $\mathrm{pH} 5.5$, containing $25 \mu \mathrm{g} / \mathrm{ml}$ of heparin glycosaminoglycan along with $0.15 \mathrm{M} \mathrm{NaCl}$ and $0.5 \mathrm{mg} / \mathrm{ml}$ of BSA (BSA-saline) at room temperature for the times indicated. In some experiments, $0.125 \mu \mathrm{g}$ of $\operatorname{rh} \beta$-pro'tryptase were incubated with various amounts of immunoaffinity purified $\mathrm{rh} \beta$-pro'tryptase or mature $\operatorname{rh} \beta$-tryptase in $100 \mu \mathrm{l}$ of the same buffer described above at room temperature. The reactions were terminated by boiling each sample in an equal volume of $2 \times$ SDS-PAGE loading buffer. Samples were then subjected to SDSPAGE and Western blotting. To examine the effects of protease inhibitors on autocatalytic processing, $0.5 \mu \mathrm{g}$ of $\operatorname{rh} \beta$-protryptase and each inhibitor were preincubated for $30 \mathrm{~min}$ at room temperature under the same conditions described above except that heparin glycosaminoglycan was omitted from the preincubation mix. Then autocatalytic processing was initiated by adding heparin glycosaminoglycan to a final concentration of $25 \mu \mathrm{g} / \mathrm{ml}$. For the effects of $\mathrm{pH}$ on autocatalytic processing of $\mathrm{rh} \beta$-protryptase, the buffers described above were used at $50 \mathrm{mM}$ over the same range of $\mathrm{pH}$ values, each also containing $25 \mu \mathrm{g} / \mathrm{ml}$ of heparin glycosaminoglycan and BSAsaline, and incubations were performed at room temperature for $1 \mathrm{~h}$.

Activation of rh $\beta$-pro'tryptase by bovine DPPI. Rh $\beta$-protryptase was incubated at $37^{\circ} \mathrm{C}$ for $1 \mathrm{~h}$ in $100 \mu \mathrm{l}$ of either $50 \mathrm{mM}$ acetate, $\mathrm{pH} 5.5$, containing BSA-saline and $25 \mu \mathrm{g} / \mathrm{ml}$ of heparin glycosaminoglycan, or $0.1 \mathrm{M}$ Mes, $\mathrm{pH} 6.5$, containing $0.1 \mathrm{M} \mathrm{NaCl}, 0.5 \mathrm{mg} / \mathrm{ml}$ of BSA and $100 \mu \mathrm{g} / \mathrm{ml}$ of dextran sulfate. After the incubation, small portions of DTT at a final concentration of $1 \mathrm{mM}$ and bovine DPPI $(0.5-10 \mu \mathrm{g} / \mathrm{ml})$ were added to the reaction mix which was then incubated at $37^{\circ} \mathrm{C}$ for varying time periods. Enzyme activity (TGPL hydrolysis) was monitored for each condition.

Purification of $r h \beta$-pro'tryptase and mature rh $\beta$-tryptase. All purification procedures were performed at $4^{\circ} \mathrm{C}$ unless otherwise stated. $\mathrm{Rh} \beta$-protryptase $(150 \mu \mathrm{g})$ was incubated in $15 \mathrm{ml}$ of $0.1 \mathrm{M} \mathrm{Mes,} \mathrm{pH}$ 6.5 , containing BSA-saline and $0.1 \mathrm{mg} / \mathrm{ml}$ of dextran sulfate at $37^{\circ} \mathrm{C}$ for $1 \mathrm{~h}$ in the presence (for generation of mature form) or absence (for generation of pro'-form) of $1 \mathrm{mM}$ DDT and $300 \mu \mathrm{g}$ of bovine DPPI. After the incubation, enzyme activities of approximately 0.6 and $30 \mathrm{TGPL} \mathrm{U} / \mathrm{mg}$ of recombinant protein were routinely detected in the preparations of $\mathrm{rh} \beta$-pro'tryptase and $\mathrm{rh} \beta$-tryptase, respectively. The samples were then cooled on ice, adjusted to $2 \mathrm{M} \mathrm{NaCl}$, and applied to an immunoaffinity column $(7 \mathrm{ml}$ bed vol) containing B2 mAb-affigel, which had been known to recognize a conformational determinant present on rh-protryptase and tissue-derived active tryptase that is unavailable on native tryptase converted to inactive monomers $(20,27)$. After loading, the column was washed with five column volumes of $10 \mathrm{mM}$ Mes, $\mathrm{pH} 6.5$, containing $1 \mathrm{M} \mathrm{NaCl}$ and 


\begin{tabular}{|c|c|c|c|c|c|}
\hline \multirow[b]{2}{*}{ Tryptase } & \multirow[b]{2}{*}{$\begin{array}{l}\text { Dextran } \\
\text { sulfate }\end{array}$} & \multicolumn{4}{|c|}{ Specific Activity } \\
\hline & & HMC-1 & Mono-Mac-6 & KU812 & $\begin{array}{c}3 \mathrm{~T} 3 \\
\text { Fibroblasts }\end{array}$ \\
\hline & & \multicolumn{4}{|c|}{$U / m g$} \\
\hline \multirow{2}{*}{ rh $\alpha$-pro } & + & 1.0 & 0 & 0 & 0 \\
\hline & - & 0 & 0 & 0 & 0 \\
\hline \multirow[t]{2}{*}{ rh $\beta$-pro } & + & 31.2 & 29.3 & 21.4 & 1.2 \\
\hline & - & 1.0 & 0.6 & 0.5 & 1.0 \\
\hline
\end{tabular}

Immunoaffinity purified $\mathrm{rh} \alpha$ - and $\mathrm{rh} \beta$-protryptase $(0.5 \mu \mathrm{g})$ were incubated with cell extracts $(0.3 \mathrm{mg}$ protein/ml $)$ in the presence $(+)$ or absence $(-)$ of dextran sulfate $(0.1 \mathrm{mg} / \mathrm{ml})$ at $37^{\circ} \mathrm{C}$ overnight as described in Methods. Specific activity with TGPL is shown as U ( $\mu \mathrm{mol}$ TGPL cleaved/min) per $\mathrm{mg}$ tryptase, the lower limit under the conditions employed being $0.1 \mathrm{U} / \mathrm{mg}$.

again with $10 \mathrm{mM}$ Mes, $\mathrm{pH}$ 6.5, containing $0.1 \mathrm{M} \mathrm{NaCl}$. Rh $\beta$-pro'tryptase and mature $\mathrm{rh} \beta$-tryptase bound and were eluted with $10 \mathrm{mM}$ diethanolamine, $\mathrm{pH} 10.0$, containing $0.2 \mathrm{M} \mathrm{NaCl}$ and $50 \%$ (vol/vol) ethylene glycol as described previously for purification of natural tryptase and $\operatorname{rh} \alpha$ - and $\operatorname{rh} \beta$-protryptase $(20,27)$. The eluted fractions were immediately neutralized with $1 \mathrm{M} \mathrm{Mes,} \mathrm{pH}$ 6.5. Preparations of mature $\mathrm{rh} \beta$-tryptase were then subjected to heparin-agarose chromatography as described for purification of tissue-derived tryptase, elution effected with a linear $\mathrm{NaCl}$ gradient $(0.45$ to $2 \mathrm{M})$ in $10 \mathrm{mM}$ Mes, $\mathrm{pH}$ 6.5 , containing $20 \%$ glycerol. Each chromatographic profile was monitored by TGPL hydrolysis and OD280. To assess purity, samples were subjected to SDS-PAGE ( $8 \mathrm{~cm}$ long $12 \%$ polyacrylamide SDS gels; Novex, San Diego, CA) in a Novex Xcell II TM Mini-Cell system. The gels were then stained with Coomassie brilliant blue R-250, destained, and scanned.

Western blotting. Samples were subjected to SDS-PAGE $(8 \mathrm{~cm}$ long $12 \%$ polyacrylamide SDS gels) under reducing conditions, and transferred electrophoretically to a supported precut nitrocellulose membrane (Novex). The membrane was then soaked in 3\% BSA to block nonspecific protein binding, and incubated overnight at $4^{\circ} \mathrm{C}$ with $0.5 \mu \mathrm{g} / \mathrm{ml}$ of the $\mathrm{G} 3 \mathrm{mAb}(21)$. Bound antibodies were detected using goat $\mathrm{IgG}$ anti-mouse Fcy conjugated with alkaline phosphatase and 5-bromo-4-chloro-3-indoyl phophate/nitroblue tetrazolium buffered substrate tablets for color development. Prestained protein molecular weight standards were used as molecular weight markers.

Analytical techniques. The $\mathrm{NH}_{2}$-terminal amino acid sequences of immunoaffinity purified $\mathrm{rh} \beta$-pro'tryptase and mature $\operatorname{rh} \beta$-tryptase ( 150 pmol of each) were determined by Commonwealth Biotechnologies Corporation (Richmond, VA) using a 470 Gas Phase Sequencer with dedicated Model 120A PTH-Amino Acid Analyzer (Applied Biosystems Inc., Foster City, CA). Protein concentrations were measured with the BCA protein assay reagent (Pierce Chemical Co., Rockford, IL) using BSA as a standard (28). Rates of hydrolysis of TGPL were determined by adding of 5-20 $\mu$ l of enzyme preparations to $1.0 \mathrm{ml}$ of $50 \mathrm{mM}$ Hepes, $\mathrm{pH} 7.4$, containing $0.15 \mathrm{M} \mathrm{NaCl}$ and 0.1 $\mathrm{mM}$ TGPL in a quartz cuvette at $25^{\circ} \mathrm{C}$ unless indicated otherwise. The amount of $p$-nitroanilide liberated from the substrate was monitored by absorbance at $405 \mathrm{~nm}$ on a Cary 2200 spectrometer (Varian Associates, Palo Alto, CA). Kinetic constants were determined by Lineweaver-Burke analyses from initial velocities of substrate cleavage at five substrate concentrations during a time period when no more than $10 \%$ of the substrate had been cleaved. Activity is expressed in $U$, where one $U$ of enzyme cleaves $1 \mu \mathrm{mol}$ of substrate per minute. A mol wt of 27,458 , calculated from the predicted amino acid sequence of the $\beta$-tryptase monomer (7), was used to calculate Kcat values. HPLC was performed with a IsoPure LC system using the Series 410 BIO LC Pump solvent delivery system (Perkin Elmer, Corp., Foster City, CA) and a Superose 12 HR 10/30 size-exclusion column $(1 \mathrm{~cm} \times 30 \mathrm{~cm}$; Pharmacia LKB, Uppsala, Sweden $)$.

\section{Results}

Activation of rh $\alpha$-protryptase and rh $\beta$-protryptase by cell extracts. To search for processing enzyme activity, cell extracts of the human leukemic cell lines HMC-1 (mast cell), MonoMac-6 (monocytic), and KU812 (basophil), and mouse 3T3 fibroblasts were combined with immunoaffinity purified rh $\alpha$ and $\mathrm{rh} \beta$-protryptase precursors in the presence of heparin, dextran sulfate, chondroitin sulfate subtypes or buffer alone over a $\mathrm{pH}$ range of from 4.0 to 9.0 at $37^{\circ} \mathrm{C}$ in $0.15 \mathrm{M} \mathrm{NaCl}$. Enzymatic activity against TGPL was strongly detected for rh $\beta$-tryptase when dextran sulfate was present with each cell extract except that from the mouse 3T3 fibroblasts (Table I). Heparin glycosaminoglycan or proteoglycan, when substituted for dextran sulfate, also facilitated the activation of $\operatorname{rh} \beta$-protryptase, whereas chondroitin sulfates $\mathrm{A}, \mathrm{B}, \mathrm{C}$, and $\mathrm{E}$ did not. Activation of $\mathrm{rh} \beta$-protryptase was optimal at pH 5.0-6.5 and was inhibited by both cysteine $(20 \mu \mathrm{M}$ E-64 and $0.1 \mathrm{mM}$ iodoacetamide) and serine protease $(50 \mu \mathrm{g} / \mathrm{ml}$ of aprotinin, 100 $\mu \mathrm{g} / \mathrm{ml}$ of SBTI and $1 \mathrm{mM}$ TPCK) inhibitors, and by Gly-Phe$\mathrm{CHN}_{2}(20 \mu \mathrm{M})$ a DPPI-specific inhibitor (16). Negligible inhibition was observed with pepstatin $(3.6 \mathrm{mM})$, EDTA $(1 \mathrm{mM})$, EGTA (1 mM), and 1-10-o-phenanthroline (2 mM). TPCK inhibits serine proteases with chymotryptic substrate specificity and DPPI (29). These data suggested that at least two types of enzymes process $\mathrm{rh} \beta$-preprotryptase, DPPI, a cysteine dipeptidase, and a serine protease.

Evidence for proteolytic processing of $r h \beta$-protryptase, but not $r h \alpha$-protryptase is shown in Fig. 1 . Note that rh $\alpha$-protryptase starting material exhibits two major and one minor bands, which appear to correspond, from top to bottom, to rh $\alpha$-protryptase with two, one, or zero $\mathrm{N}$-linked glycosylation sites being occupied (20). Rh $\beta$-protryptase also exhibits heterogeneity, showing two major bands corresponding to N-glycosylated $(30.7 \mathrm{kD})$ and nonglycosylated $(30.2 \mathrm{kD})$ species $(20)$. The apparent molecular weights of these bands were determined empirically based on their electrophoretic mobilities relative to those of commercial standards. Minor bands in the rh $\beta$-protryptase preparation migrating with the autoprocessed products also can be discerned $(<10 \%$ of total tryptase by band densitometry). A shift in the electrophoretic mobilities of the two major $\mathrm{rh} \beta$-protryptase proteins, corresponding to an apparent loss of less than $500 \mathrm{D}$ from each, consistent with limited proteolytic processing, was detected by SDS-PAGE/Western blotting in all cases where enzyme activity was observed 


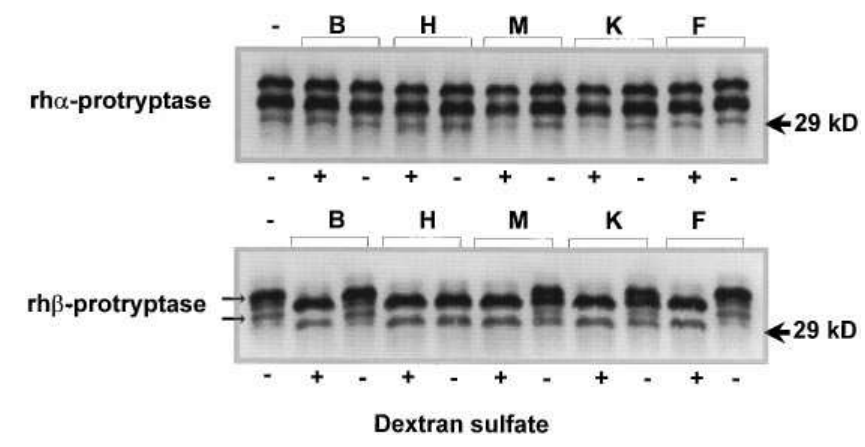

Figure 1. Analysis of the processing of $\operatorname{rh} \beta$-protryptase and rh $\alpha$-protryptase in buffer $(B)$ and in extracts of HMC-1 $(H)$, Mono Mac-6 $(M)$, KU812 $(K)$, and $3 \mathrm{~T} 3$ fibroblasts $(F)$ in the presence $(+)$ and absence $(-)$ of dextran sulfate. Lanes labeled at the top as $(-)$ show starting material. Incubations were for $12 \mathrm{~h}$ at $37^{\circ} \mathrm{C}$. Tryptase in each reaction mixture (50 ng/lane) was denatured, reduced, and subjected to Western blotting with the G3 mAb as described in Methods. A $29-\mathrm{kD}$ mol wt standard is shown to the right of each blot. Two small arrows to the left of the lower blot point to glycosylated and nonglycosylated bands of rh $\beta$-protryptase. The less intense bands just below each of these presumably correspond to $\mathrm{rh} \beta$-pro'tryptase.

(Fig. 1). Proteolytic processing also was observed in the presence of heparin and either the fibroblast extract or buffer alone, conditions that did not result in enzymatic activity (Fig. 1). Proteolytic processing in the presence of HMC-1 extract without exogenous heparin also was observed, even though enzymatic activation was not apparent. This might be attributable to small amounts of endogenous tryptase and heparin present in the HMC-1 extracts (see below). No detectable activation or proteolytic processing of rh $\alpha$-protryptase precursor was observed by incubation with the cell extracts under any of the conditions.

Autocatalytic processing of rh $\beta$-protryptase to rh $\beta$-pro'tryptase. Based on the above findings, two sequential steps of proteolytic processing of $r h \beta$-protryptase were postulated; a heparin-dependent autocatalytic step and a DPPI-dependent step. The autocatalytic step is demonstrated in Fig. 2. After $1 \mathrm{~h}$ of incubation autoprocessing of $\mathrm{rh} \beta$-protryptase occurs only in the presence of heparin, as reflected by a decrease in apparent size of the two major bands (Fig. $2 A$ ). Autoprocessing in the presence of heparin exhibits an acid pH optimum of 5.5-6.0 (Fig. 2 B). In the presence of dextran sulfate the $\mathrm{pH}$ optimum is 6.0-6.5 (not shown). Autoprocessing was inhibited best by aprotinin $(\sim 60 \%$ inhibition by densitometry), weakly by diisopropyl fluorophosphate, and not at all by cysteine, aspartic acid, or metallo protease inhibitors (Fig. $2 \mathrm{C}$ ). Of biologic interest, chondroitin sulfates A, B, C, and E could not substitute for heparin and facilitate autoprocessing of tryptase (Fig. $2 D$ ).

Autocatalytically produced $\mathrm{rh} \beta$-protryptase was purified by $\mathrm{B} 2 \mathrm{mAb}$ immunoaffinity chromatography and subjected to five cycles of amino acid sequencing. A single sequence of ValGly-Ile-Val-Gly was obtained, indicating the autocatalytic cleavage site is $\mathrm{Arg}^{-3} / \mathrm{Val}^{-2}$, consistent with tryptase having a specificity for basic residues. This probably explains why the rh $\alpha$-tryptase precursor, which contains $\mathrm{Gln}^{-3} / \mathrm{Val}^{-2}$ is not autocatalytically processed in vitro. The calculated size of the released peptide is $1,170 \mathrm{D}$, somewhat greater than the apparent loss in mol wt observed by SDS-PAGE.

Autocatalytic processing of $\mathrm{rh} \beta$-protryptase appears to be
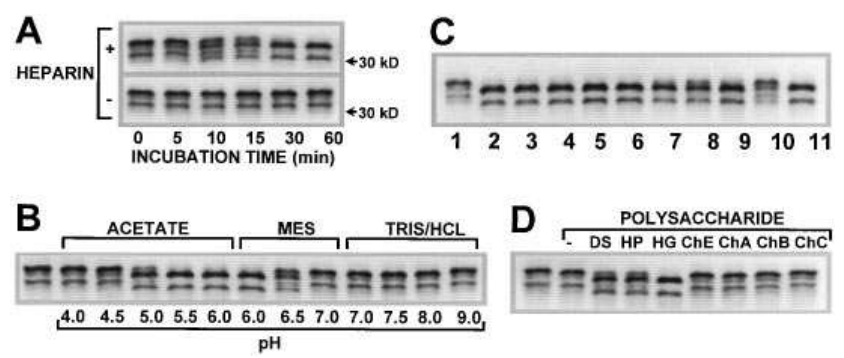

Figure 2. Autoprocessing of rh $\beta$-protryptase to $\mathrm{rh} \beta$-pro'tryptase. Autoprocessing was analyzed by Western blotting using the G3 antitryptase $\mathrm{mAb}(21)$. The time course $(A), \mathrm{pH}$ optimum $(B)$, protease inhibitor profile $(C)$, and polysaccharide requirements $(D)$ are shown. In each case $\mathrm{rh} \beta$-preprotryptase $(5 \mu \mathrm{g} / \mathrm{ml})$ was incubated in $50 \mathrm{mM}$ buffer containing BSA-saline at room temperature for $1 \mathrm{~h}$ or the times indicated. Polysaccharides were tested at $25 \mu \mathrm{g} / \mathrm{ml}$. The time course in $A$ used $50 \mathrm{mM}$ acetate, $\mathrm{pH}$ 5.5. In $B$ and $C$ lane 1 shows a rh $\beta$-protryptase unincubated control. In $C \operatorname{rh} \beta$-protryptase was preincubated alone (lane 2) or with a protease inhibitor as follows: pepstatin A $(10 \mu \mathrm{M})$ (lane 3), E-64 $(20 \mu \mathrm{M})$ (lane 4), iodoacetamide $(1 \mathrm{mM})$ (lane 5), EDTA (1 mM) (lane 6), DFP (1 mM) (lane 7), 3,4-dichloroisocoumarin $(250 \mu \mathrm{M})$ (lane 8$)$, SBTI $(100 \mu \mathrm{g} / \mathrm{ml})$ (lane $9)$, aprotinin $(50 \mu \mathrm{g} / \mathrm{ml})($ lane 10$)$ or TPCK $(1 \mathrm{mM})$ (lane 11$)$ in acetate buffer, $\mathrm{pH}$ 5.5, containing BSA-saline at room temperature for $60 \mathrm{~min}$. After the preincubation, autoprocessing was initiated by adding heparin to each sample and incubating the mixtures at room temperature for $60 \mathrm{~min}$. Lane numbers are shown under the blot. By themselves, the solvents used for dissolving the inhibitors did not affect autoprocessing (data not shown). In $D$, dextran sulfate $(D S)$, porcine chondroitin sulfate $\mathrm{A}(C h A)$, porcine chondroitin sulfate $\mathrm{B}$ $(C h B)$, shark chondroitin sulfate $\mathrm{C}(\mathrm{ChC})$, rat serosal mast cell heparin proteoglycan $(H P)$, heparin glycosaminoglycan $(H G)$, and murine chondroitin sulfate $\mathrm{E}(C h E)$ were used as indicated.

inter rather than intramolecular, because the relative rate of conversion, as measured by the time to $50 \%$ cleavage, increased as the concentration of $r h \beta$-protryptase was increased, being $50,25,12$, and $6 \mathrm{~min}$ at $1.25,2.5,5$, and $12.5 \mu \mathrm{g} / \mathrm{ml}$, respectively, as shown in Fig. $3 A$. Intramolecular processing should display kinetics that are independent of enzyme concentration, as shown for hedgehog (30) and cathepsin B (31) precursor proteins. Whether tryptase autoprocessing activity is due to rh $\beta$-protryptase, contaminant putative $\mathrm{rh} \beta$-pro'tryptase, or both also was considered. Approximately $10 \%$ of the total tryptase by Western blotting with G3 mAb migrates with rh $\beta$-pro'tryptase, and yields the amino acid sequence found for $r h \beta$-pro'tryptase (see below), suggesting that processing to rh $\beta$-pro'tryptase can occur at a slow rate in the insect cell system. Nevertheless, rh $\beta$-protryptase preparations expressed no detectable enzymatic activity using TGPL $(<0.1 \mathrm{U} / \mathrm{mg}$ tryptase). Thus, the substrate specificity of $\mathrm{rh} \beta$-protryptase is quite restrictive. As shown in Fig. $3 B$, incubation of purified $\mathrm{rh} \beta$-pro'tryptase $(1.25 \mu \mathrm{g} / \mathrm{ml})$ with $\mathrm{rh} \beta$-protryptase $(1.25 \mu \mathrm{g} /$ $\mathrm{ml})$ at $\mathrm{pH} 5.5$ accelerated autoprocessing to about the same extent as when $\mathrm{rh} \beta$-protryptase was increased to $2.5 \mu \mathrm{g} / \mathrm{ml}$, suggesting that both precursor forms could participate in autoprocessing. Mature rh $\beta$-tryptase was very potent at processing $\mathrm{rh} \beta$-protryptase $(1.25 \mu \mathrm{g} / \mathrm{ml}), 0.01 \mu \mathrm{g} / \mathrm{ml}$ of the mature enzyme decreasing the time to $50 \%$ cleavage from 50 to $8 \mathrm{~min}$ at pH 5.5. Interestingly, in spite of enzymatic activity against TGPL being optimal at neutral $\mathrm{pH}$ for both mature and rh $\beta$-pro'tryptase, the rate of autoprocessing was at least 10- 
fold faster at the acidic $\mathrm{pH}$ (Fig. 3 B). Commercial bovine trypsin also appeared to catalyze conversion of $\operatorname{rh} \beta$-protryptase to $\operatorname{rh} \beta$-pro'tryptase (Fig. $3 C$ ), but this reaction was heparin-independent, occurred better at neutral than acidic $\mathrm{pH}$, and required at least 10-fold greater amounts of trypsin than tryptase to achieve the same rate.

Activation of rh $\beta$-pro'tryptase by bovine DPPI. DPPI, based on preliminary experiments with extracts of bone marrowderived leukemic cells, was assessed directly for its ability to remove the dipeptide $\left(\mathrm{Val}^{-2}-\mathrm{Gly}^{-1}\right)$ present at the $\mathrm{NH}_{2}$ terminus of $\beta$-pro'tryptase and yield active tryptase. As shown in Fig. $4 A$, DPPI, in the presence of dextran sulfate, converted $\mathrm{rh} \beta$-pro'tryptase into enzymatically active $\mathrm{rh} \beta$-tryptase, which exhibited a sp act $(31.1 \pm 2.9 \mathrm{U} / \mathrm{mg}$ of tryptase; mean $\pm \mathrm{SD}, n=$ 4), Kcat $\left(1,016 \mathrm{~min}^{-1}\right)$ and $K_{\mathrm{m}}(1.3 \mathrm{mM})$ for TGPL in Hepes
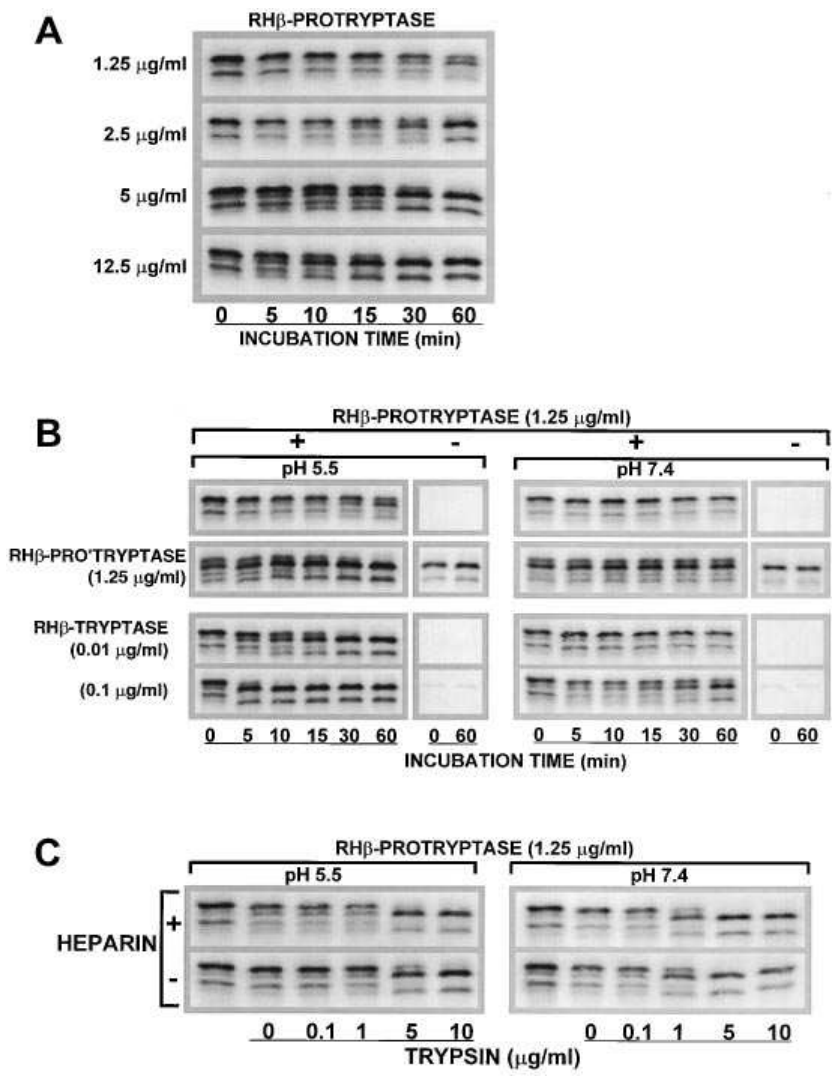

Figure 3. Intermolecular autoprocessing of $\operatorname{rh} \beta$-protryptase to $\operatorname{rh} \beta$ pro'tryptase. Autoprocessing was analyzed as detailed in Figure 2. A shows the effect of varying the concentration of $\operatorname{rh} \beta$-protryptase $(1.25-12.5 \mu \mathrm{g} / \mathrm{ml})$ on the rate of autoprocessing in acetate buffer, $\mathrm{pH}$ 5.5 , containing BSA-saline and heparin $(25 \mu \mathrm{g} / \mathrm{ml})$, at room temperature for up to $60 \mathrm{~min}$. $B$ shows the effects of adding $\mathrm{rh} \beta$-pro'tryptase $(1.25 \mu \mathrm{g} / \mathrm{ml})$ or mature $\operatorname{rh} \beta$-tryptase $(0.01$ and $0.1 \mu \mathrm{g} / \mathrm{ml})$ on autoprocessing of $\mathrm{rh} \beta$-protryptase $(1.25 \mu \mathrm{g} / \mathrm{ml})$ at $\mathrm{pH} 5.5$ as in $A$ or at $\mathrm{pH} 7.4$ in Hepes buffer containing BSA-saline and heparin $(25 \mu \mathrm{g} / \mathrm{ml})$, in each case at room temperature. Panels labeled (-) lack $\mathrm{rh} \beta$-protryptase and contain only the added $\mathrm{rh} \beta$-pro'tryptase or $\operatorname{rh} \beta$-tryptase, while those labeled $(+)$ contain all reaction components. $C$ shows the ability of bovine trypsin $(0-10 \mu \mathrm{g} / \mathrm{ml})$ to stimulate autoprocessing of $\mathrm{rh} \beta$-protryptase $(1.25 \mu \mathrm{g} / \mathrm{ml})$ at $\mathrm{pH} 5.5$ and $\mathrm{pH} 7.4$ during a 10-min incubation at room temperature in the presence or absence of heparin $(25 \mu \mathrm{g} / \mathrm{ml})$. Lane 1 shows an unincubated $\mathrm{rh} \beta$-protryptase control at both $\mathrm{pH} 5.5$ and $\mathrm{pH} 7.4$.

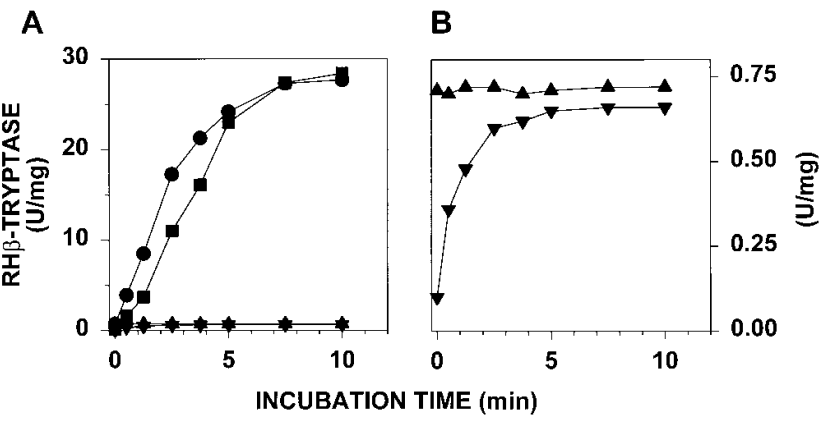

Figure 4. Activation of $\mathrm{rh} \beta$-pro'tryptase to mature $\operatorname{rh} \beta$-tryptase by DPPI. In $A$ immunoaffinity purified $\mathrm{rh} \beta$-pro'tryptase $(0.5 \mu \mathrm{g})$ was incubated in the presence $(\bullet)$ or absence $(\boldsymbol{\Lambda})$ of $1 \mu \mathrm{g}$ of bovine DPPI at $37^{\circ} \mathrm{C}$ in $100 \mu \mathrm{l}$ of Mes buffer, $\mathrm{pH} 6.5$, containing BSA-saline, $100 \mu \mathrm{g} /$ $\mathrm{ml}$ of dextran sulfate, $1 \mathrm{mM}$ dithiothreitol. Also shown is the time course for processing $0.5 \mu \mathrm{g}$ of rh $\beta$-protryptase under the same conditions in the presence $(\boldsymbol{\square})$ and absence $(\boldsymbol{\nabla})$ of $1 \mu \mathrm{g}$ of DPPI. At the times indicated, portions of each incubation mixture were removed and immediately added to a cuvette containing TGPL as described above to determine initial reaction velocities. In $B$ the y-axis is expanded 250-fold to show the data in $A$ for $\operatorname{rh} \beta$-pro'tryptase ( $\boldsymbol{\Delta})$ and $\operatorname{rh} \beta$-protryptase $(\boldsymbol{\nabla})$ in the absence of DPPI.

buffer, $\mathrm{pH} 7.4$, containing $0.15 \mathrm{M} \mathrm{NaCl}$, that were similar to those observed for immunoaffinity purified, skin-derived tryptase (31 U/mg, $972 \mathrm{~min}^{-1}$, and $1.4 \mathrm{mM}$, respectively). Active $\mathrm{rh} \beta$-tryptase also formed after addition of rh $\beta$-protryptase under the same conditions, but with a slight lag period due to the time of autoprocessing (accelerated processing probably occurred as fully active tryptase formed). As shown in Fig. $4 B$, rh $\beta$-pro'tryptase exhibits trace enzymatic activity against TGPL at neutral $\mathrm{pH}(\sim 0.7 \mathrm{U} / \mathrm{mg})$; no detectable activity against this synthetic substrate was detected at $\mathrm{pH} 5.5$ (not shown). In the presence of aprotinin TGPL-cleaving activity of rh $\beta$-pro'tryptase was $>80 \%$ inhibited at $\mathrm{pH} 7.4$, in contrast to the relative resistance of the native tryptase and $\operatorname{rh} \beta$-tryptase to this inhibitor. $\mathrm{Rh} \beta$-protryptase exhibited no detectable enzyme activity at pH 7.4 (Fig. 4 B) or pH 5.5 (not shown). Although heparin was not necessary for the DPPI-catalyzed removal of the $\mathrm{NH}_{2}$ terminal dipeptide as determined by $\mathrm{NH}_{2}$-terminal amino acid sequencing, production of enzymatically-active rh $\beta$-tryptase did require heparin. Furthermore, as in the autoprocessing step heparin glycosaminoglycan and proteoglycan could replace dextran sulfate, whereas chondroitin sulfates A, B, C, and E could not (data not shown).

Heterogeneity in the staining patterns of $\operatorname{rh} \alpha$ - and $\operatorname{rh} \beta$ tryptase species after SDS-PAGE diminished after treatment with $\mathrm{N}$-glycosidase $\mathrm{F}$ (Fig. $5 A$ ). For rh $\alpha$-preprotryptase, the digestion product yielded one major band as described (20), consistent with most molecules having either one or two potential N-glycosylation sites occupied before deglycosylation. For rh $\beta$-protryptase, rh $\beta$-pro'tryptase, and $r h \beta$-tryptase the digestion products for each also yielded a single major band that migrated with the lower mol wt band present before digestion, indicating that the single putative $\mathrm{N}$-glycosylation site of these species is either occupied or unoccupied before digestion.

In Fig. $5 B$ the relative binding affinities of rh $\beta$-protryptase, rh $\beta$-pro'tryptase, rh $\beta$-tryptase, human skin-derived tryptase, and bovine trypsin to heparin-agarose were compared at $\mathrm{pH}$ 5.5 and $\mathrm{pH}$ 7.4. At $0.15 \mathrm{M} \mathrm{NaCl}$ each form of tryptase, but not 

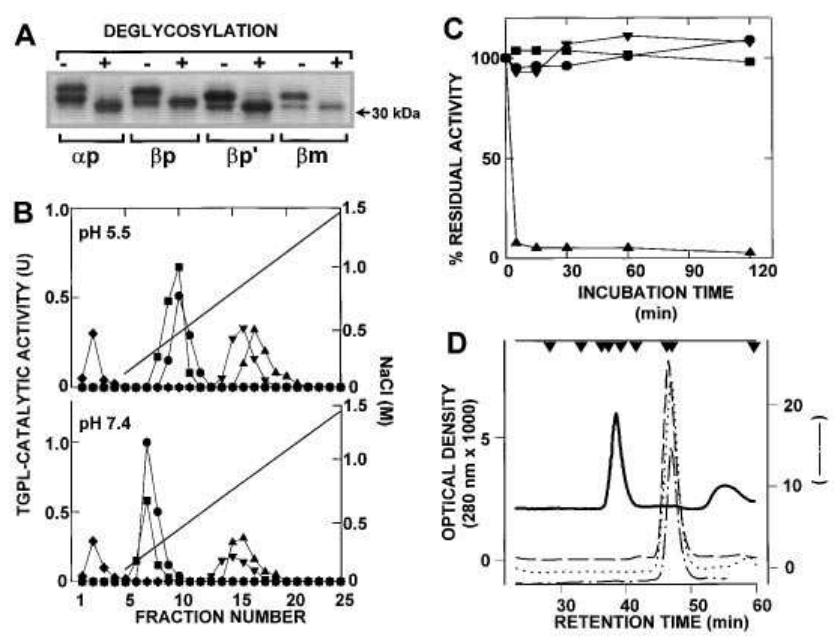

Figure 5. Comparative properties of different forms of rh-tryptase. In $A$ immunoaffinity purified and denatured rh $\alpha$-protryptase $(\alpha p)$, $\operatorname{rh} \beta$-protryptase $(\beta p), \operatorname{rh} \beta$-pro'tryptase $\left(\beta p^{\prime}\right)$ and mature $\operatorname{rh} \beta$-tryptase $(\beta m)(2 \mu \mathrm{g}$ of each) were treated with $\mathrm{N}$-glycosidase $\mathrm{F}(+)$ according to the manufacturer's instructions or with buffer alone (-), subjected to SDS-PAGE, and stained with Coomassie brilliant blue R-250. The position of the $30,000 \mathrm{kD}$ marker (carbonic anhydrase) is shown to the right. In $B$ heparin-agarose chromatography profiles for immunoaffinity purified $\operatorname{rh} \beta$-protryptase $(\bullet), \operatorname{rh} \beta$-pro'tryptase $(\boldsymbol{\square}), \operatorname{rh} \beta$ tryptase $(\boldsymbol{\Lambda})$, and human skin-derived tryptase $(\boldsymbol{\nabla})(50 \mu \mathrm{g}$ of each), and $20 \mu \mathrm{g}$ of bovine trypsin ( ) are shown. Samples were loaded in $1 \mathrm{ml}$ of $50 \mathrm{mM}$ acetate, $\mathrm{pH} 5.5$, or $50 \mathrm{mM}$ Hepes, $\mathrm{pH} 7.4$, both containing BSA-saline and $20 \%(\mathrm{vol} / \mathrm{vol})$ glycerol, at $4{ }^{\circ} \mathrm{C}$ onto $1.5 \mathrm{ml}$ (bed volume) of heparin-agarose equilibrated with loading buffer. After washing with $3 \mathrm{ml}$ of loading buffer, elution of bound material was performed with a $25 \mathrm{ml}$ linear gradient of $0.15-1.5 \mathrm{M} \mathrm{NaCl}$ at the same $\mathrm{pH}$ as the loading buffer. Fractions $(1.2 \mathrm{ml})$ were collected and assayed for $\mathrm{NaCl}$ concentration $(-)$ by conductivity measurements and for TGPL-cleaving activity for $\mathrm{rh} \beta$-tryptase, human skin-derived tryptase and bovine trypsin. For detection of rh $\beta$-protryptase and rh $\beta$-pro'tryptase in column fractions, TGPL-cleaving activity was measured after conversion to enzymatically active $\operatorname{rh} \beta$-tryptase. The stability of $\operatorname{rh} \beta$-tryptase was assessed in $C$. Rh $\beta$-protryptase (๑), rh $\beta$-pro'tryptase ( $\mathbf{\square})$, and $\mathrm{rh} \beta$-tryptase $(\mathbf{\Lambda})(50 \mu \mathrm{g} / \mathrm{ml}$ of each) were incubated in $50 \mathrm{mM}$ Hepes, $\mathrm{pH} 7.4$, containing BSA-saline at $37^{\circ} \mathrm{C}$ for up to $2 \mathrm{~h}$. $\mathrm{Rh} \beta$-tryptase also was incubated in the same buffer containing $250 \mu \mathrm{g} / \mathrm{ml}$ of heparin $(\boldsymbol{\nabla})$. TGPL-catalytic activities, expressed as the percent residual activity compared to the 0-min control, were measured directly for $\mathrm{rh} \beta$-tryptase and after processing to mature tryptase for $\mathrm{rh} \beta$-protryptase and $\mathrm{rh} \beta$-pro'tryptase. The quaternary structures of immunoaffinity purified rh $\alpha$-protryptase and $\mathrm{rh} \beta$-tryptase subtypes were assessed by gel filtration chromatography in $D$. Rh $\alpha$-protryptase $(2 \mu \mathrm{g})(\cdots \cdots), \operatorname{rh} \beta$-preprotryptase $(5 \mu \mathrm{g})(-\cdot)$, rh $\beta$-pro'tryptase $(1.5 \mu \mathrm{g})(---)$, rh $\beta$-tryptase $(0.7 \mu \mathrm{g})(-)$ in $200 \mu \mathrm{l}$ of $10 \mathrm{mM}$ Mes, pH 6.5, containing $1.0 \mathrm{M} \mathrm{NaCl}$, were applied to a Superose 12 HPLC column equilibrated with the same buffer. A flow rate of $0.3 \mathrm{ml} / \mathrm{min}$ was used, and fractions of $0.24 \mathrm{ml}$ were collected. Mol wt standards (arrowheads) from left to right included dextran blue $\left(2 \times 10^{6} \mathrm{D}\right)$, thyroglobulin $(669,000 \mathrm{D})$, apoferritin $(443,000 \mathrm{D})$, catalase $(232,000 \mathrm{D})$, aldolase $(158,000 \mathrm{D})$, BSA $(66,000 \mathrm{D})$, ovalbumin (43,000 D), chymotrypsinogen (25,000 D), and acetone (58 D). Elution of standards and tryptase species were monitored by absorbance at $280 \mathrm{~nm}$.

trypsin, bound to heparin-agarose. Using a linear salt gradient for elution at $\mathrm{pH} 5.5, \mathrm{rh} \beta$-protryptase and $\mathrm{rh} \beta$-pro'tryptase emerged at $0.46 \mathrm{M}$ and $0.48 \mathrm{M} \mathrm{NaCl}$, respectively, whereas mature $\mathrm{rh} \beta$-tryptase eluted at $0.99 \mathrm{M} \mathrm{NaCl}$, indicating a stronger affinity for heparin than the precursors, but similar to that of native skin-derived tryptase, which eluted at $0.82 \mathrm{M} \mathrm{NaCl}$. At $\mathrm{pH} \mathrm{7.4,} \mathrm{elution} \mathrm{of} \mathrm{each} \mathrm{form} \mathrm{of} \mathrm{tryptase} \mathrm{occurred} \mathrm{at} \mathrm{a} \mathrm{NaCl}$ concentration $\sim 0.1 \mathrm{M}$ lower than at $\mathrm{pH}$ 5.5.

The stability of $r h \beta$-tryptase was compared to that of $r h \beta$ tryptase precursors in Fig. $5 C$. $\mathrm{Rh} \beta$-tryptase was stable in the presence of heparin over the 2-h incubation, but in the absence of heparin, almost all of its enzymatic activity was lost by 5-10 min. This behavior is similar to that reported for tissue-derived tryptase (17). Rh $\beta$-protryptase and $\mathrm{rh} \beta$-pro'tryptase, unlike the mature enzyme, were stable when incubated at $\mathrm{pH} 7.4$ in the absence of heparin or dextran sulfate, because both could then be processed to active enzyme. $\mathrm{Rh} \beta$-tryptase in the presence of heparin was sensitive to DFP ( $98 \%$ inhibition) and PMSF (66\% inhibition), and relatively resistant to SBTI $(<10 \%$ inhibition) and aprotinin (30\% inhibition), and to aspartic, cysteine, and metallo protease inhibitors $(<10 \%$ inhibition), essentially identical to the behavior of native tryptase. However, it is also of interest to note that the autoprocessing step was sensitive to aprotinin and was only slightly inhibited by SBTI and DFP ( 10\% by densitometry). The difference in susceptibility to aprotinin may reflect conformational differences between the mature active tetrameric enzyme and the monomeric precursor (see below).

The quaternary structures of tryptase at various stages of processing were examined by Superose 12 FPLC as shown in Fig. 5 D. Rh $\alpha$-protryptase, $r h \beta$-protryptase, and rh $\beta$-pro'tryptase each migrated as a monomer at an apparent mol wt of 25,000 D. In contrast, mature, enzymatically active $\mathrm{rh} \beta$-tryptase migrated at an apparent mol wt of $107,000 \mathrm{D}$, consistent with a tetrameric structure. $\mathrm{Rh} \beta$-tryptase, like native tryptase, migrated as a monomer both after inactivation by incubation in physiologic buffer without heparin and also after processing by DPPI in the absence of heparin (not shown).

\section{Discussion}

The two proteolytic steps involved in the processing of recombinant human tryptase are summarized in Fig. 6. The dependence of both autoprocessing and formation of active tetramer after DPPI processing on either heparin glycosaminoglycan, heparin proteoglycan or dextran sulfate indicates that, like stabilization of the enzymatically active tetramer (32), negative charge density rather than carbohydrate sequence determines efficacy. The requirement for acid $\mathrm{pH}$ at each processing step is not dictated by a lack of binding to heparin at neutral $\mathrm{pH}$, because human tryptase precursors like the mature enzyme bind to heparin at neutral and acidic $\mathrm{pH}$ when the ionic strength corresponds to $0.15 \mathrm{M} \mathrm{NaCl}$. Thus, unlike mouse mast cell protease 7 (19), histidine residues in human $\beta$-protryptase are not critical for binding to heparin. For autoprocessing catalyzed both by mature tryptase and by precursors, acid $\mathrm{pH}$ may influence either the conformation of the signal peptide substrate, or the substrate specificity of the catalytic enzyme. For conversion of $\mathrm{rh} \beta$-pro'tryptase to the active enzyme, acid $\mathrm{pH}$ is optimal in general for DPPI, and also may be critical for conversion of monomer to tetramer.

Although human tryptase is considered primarily to function in the extracellular space near neutral $\mathrm{pH}$, its autoprocessing activity at acid $\mathrm{pH}$ indicates an intracellular enzymatic function as well. Whether this activity might extend to other precursor proteins or to the metabolism of released activation 


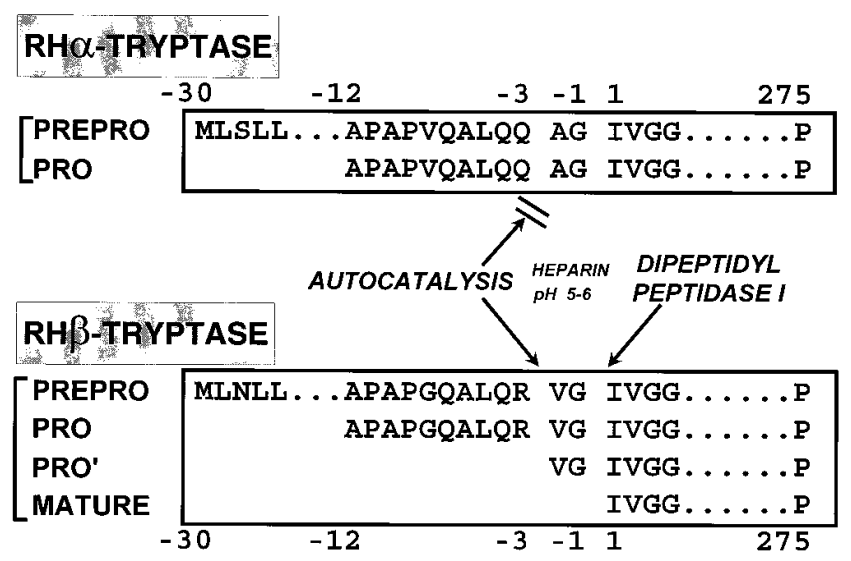

Figure 6. Summary of the processing of human $\alpha$ - and $\beta$-tryptase. Three to five cycles of $\mathrm{NH}_{2}$-terminal amino acid sequence analyses were performed on immunoaffinity purified $\operatorname{rh} \alpha$-protryptase, $\operatorname{rh} \beta$ protryptase, rh $\beta$-pro'tryptase, and $r h \beta$-tryptase. Sequencing was performed by Commonwealth Biotechnology Laboratory, Inc. (Richmond, VA). The scheme shown is based on this data, on the sequences predicted from the corresponding cDNA molecules, and the previously determined sequence for tissue-derived tryptase.

peptides should be considered. Another point of interest is the low level of rh $\beta$-pro'tryptase activity found against the synthetic peptide substrate. This property is compatible with chymotryptic proenzymes from granulocytes that exhibit low levels of activity against small synthetic substrates but do not cleave protein substrates (12). Of further interest is the finding that $\mathrm{rh} \beta$-pro'tryptase activity against TGPL at neutral $\mathrm{pH}$ is sensitive to inhibition by aprotinin, in contrast to the active tetramer. The polar residues in the activation dipeptides of most chymases and granzymes inhibit penetration of the $\mathrm{NH}_{2}$-terminal amino acids of the mature portion of the enzyme into the hydrophobic interior, where a salt bridge between $\mathrm{NH}_{2}$-terminal Ile and the carboxylate side chain of an Asp residue near the active site form to obtain optimal enzymatic activity, analogous to chymotrypsin (33). The tryptase activation dipeptide contains hydrophobic residues, but these still should prevent ion binding of $\mathrm{Ile}^{1}$ to $\mathrm{Asp}^{193}$.

The intracellular site(s) for processing of tryptase precursors, though not directly addressed in the current study, can be considered. Tryptase precursors should be stable until they associate with heparin, permitting autoprocessing to occur in an acid $\mathrm{pH}$ environment, presumably in the trans-Golgi network, secretory pregranules, and secretory granules (34). Heparin, analogous to chondroitin sulfate subtypes, is expected to be present in the Golgi apparatus, because xylosylation of core protein leading to formation of chondroitin sulfate proteoglycans begins in the endoplasmic reticulum, and continues in the Golgi where chain elongation and sulfation also occur $(35,36)$. Mast cells, like other bone marrow-derived granulocytes, store DPPI inside post-Golgi secretory granules $(12,16)$, where the activation dipeptides for cathepsin $\mathrm{G}$ and elastase $(37,38)$, like tryptase, are removed. Any $\beta$-protryptase arriving in the secretory granule should be processed rapidly by active tryptase already in residence. The current study shows that $0.1 \mu \mathrm{g} / \mathrm{ml}$ of active tryptase completely converts $1.25 \mu \mathrm{g} / \mathrm{ml}$ of $\mathrm{rh} \beta$-protryptase to the dipeptide pro'enzyme within $\sim 10 \mathrm{~min}$ at $\mathrm{pH}$ 5.5; however, the concentration of active tryptase in secretory granules of tissue mast cells is estimated to be at least $100 \mathrm{mg} /$ $\mathrm{ml}$. The higher potency of $\operatorname{rh} \beta$-tryptase relative to its precursors raises the possibility that minor contamination of precursor tryptase preparations with mature tryptase or with another processing enzyme could account for the apparent autoprocessing activity of the precursor forms of tryptase. To address this point, heparin-agarose chromatography of rh $\beta$-pro/pro'tryptase was performed under conditions that clearly separate precursor from mature active tryptase (Fig. $5 \mathrm{C}$ ). The rates of autocatalytic processing of $\mathrm{rh} \beta$-pro/pro'tryptase before and after heparin-agarose chromatography were not substantially different, making it likely that autocatalytic processing by tryptase precursors was occurring.

Trimming of tryptase signal peptides in Sf-9 cells to $\mathrm{Ala}^{-12}$ Pro $^{-11}$ suggests intrinsic DPPI-like activity that is stopped by Pro in the $\mathrm{P} 1$ position. However, the lack of heparin proteoglycan in these cells, even if the precursor passes through an acid $\mathrm{pH}$ milieu, should prohibit further meaningful processing. Whether proteases other than tryptase can process $\beta$-protryptase to $\beta$-pro'tryptase remains to be seen; trypsin, for example, has only a limited capacity to carry out this step. Cells that might be induced to express tryptase mRNA and protein in the absence of heparin, like the experimental Sf- 9 cells, would not be expected to produce active enzyme. In Fig. 1, proteolytic processing of $\mathrm{rh} \beta$-protryptase by an HMC- 1 extract occurred in the absence of exogenous heparin or dextran sulfate, but without tryptase enzymatic activation. Most likely, endogenous heparin-stabilized tryptase and DPPI removed the propeptide, but insufficient heparin was available to permit formation and stabilization of tetrameric $\mathrm{rh} \beta$-tryptase. In vivo, human basophils, which express small amounts of tryptase mRNA and protein, should not be able to efficiently process the enzyme unless heparin synthesis also could be induced. Although the $\mathrm{NH}_{2}$ terminus of mature $\beta$-tryptase $\left(\mathrm{Ile}^{1}-\mathrm{Val}^{2}-\mathrm{Gly}^{3}-\mathrm{Gly}^{4}-\mathrm{Gln}^{5}-\mathrm{Glu}^{6} \ldots\right)$ does not contain a stop sequence for DPPI (P1 Pro or P2 Arg), digestion ceases at the 1 position, suggesting a conformational change occurs immediately after dipeptide removal to protect the $\mathrm{NH}_{2}$ terminus.

The current mechanism of autoprocessing yields an active homotetramer of $\mathrm{rh} \beta$-tryptase. This is likely to be the exclusive form of active tryptase in humans. However, it remains possible that allelic variations or multiple genes of $\beta$-tryptase exist. The model for tryptase processing predicts that the rh $\alpha$ tryptase precursor, with an $\mathrm{Arg}^{-3} / \mathrm{Gln}^{-3}$ substitution, cannot be processed by tryptase, and therefore will not become enzymatically active unless a different processing mechanism exists. Murine and canine tryptases contain $\mathrm{Arg}^{-3}$, suggesting they undergo a similar processing pathway to human $\beta$-tryptase. Thus, the association of heparin and tryptase in mast cell secretory granules in different species probably relates to a dependence on heparin for processing of tryptase at acid $\mathrm{pH}$. The requirement for heparin to stabilize the active enzyme at neutral $\mathrm{pH}$ pertains primarily to human tryptase.

Human $\alpha$-tryptase is the predominant form of the enzyme detected by immunoassay in serum from normal subjects and is the predominant form that is elevated in the serum from subjects with systemic mastocytosis (10). In contrast, $\beta$-tryptase is the predominant form found by immunoassay in the serum from subjects undergoing severe systemic anaphylactic reactions, and is the predominant form detected in tissue mast cells. The inability to autoprocess $\alpha$-tryptase precursor may explain this data indicating that $\alpha$-tryptase is not stored in secretory granules but instead is constitutively secreted (10). We hy- 
pothesize that failure to process the propeptide of the $\alpha$-tryptase precursor diverts it from trafficking to the secretory granules to a pathway leading to its constitutive secretion.

\section{Acknowledgments}

We thank Dr. Dean Metcalfe (National Institutes of Health, Bethesda, MD) for providing chondroitin sulfate E, Dr. William Serafin (Vanderbilt University, Nashville, TN) for providing Gly-Phe- $\mathrm{CHN}_{2}$, Dr. Gerald Gleich and Dr. Joseph Butterfield (Mayo Clinic, Rochester, MN) for contributing the HMC-1 cell line, and Dr. G. Nilsson (University of Uppsala, Uppsala, Sweden) for donating the KU812 cell line, and Dr. H.W. Ziegler-Heitbrock (University of Munich, Munich, Germany) for providing the Mono Mac-6 cell line.

This work was supported by National Institutes of Health grant AI-20487.

\section{References}

1. Schwartz, L.B. 1994. Tryptase: a mast cell serine protease. Meth. Enzymol. 244:88-100.

2. Schwartz, L.B., R.A. Lewis, D. Seldin, and K.F. Austen. 1981. Acid hydrolases and tryptase from secretory granules of dispersed human lung mast cells. J. Immunol. 126:1290-1294.

3. Schwartz, L.B. 1994. Laboratory assessment of immediate hypersensitivity and anaphylaxis: utilization of tryptase as a marker of mast cell-dependent events. In Immunology and Allergy Clinics of North America: Diagnostic Laboratory Immunology. D.P. Huston, editor. W.B. Saunders Co., Philadelphia. 339-350.

4. Caughey, G.H. 1994. Serine proteinases of mast cell and leukocyte granules: A league of their own. Am. J. Respir. Crit. Care Med. 150 (Suppl.):S138S142.

5. Tanaka, R.D., J.M. Clark, R.L. Warne, W.M. Abraham, and W.R. Moore. 1995. Mast cell tryptase: a new target for therapeutic intervention in asthma. Int. Arch. Allergy Immunol. 107:408-409.

6. Miller, J.S., E.H. Westin, and L.B. Schwartz. 1989. Cloning and characterization of complementary DNA for human tryptase. J. Clin. Invest. 84:11881195.

7. Miller, J.S., G. Moxley, and L.B. Schwartz. 1990. Cloning and characterization of a second complementary DNA for human tryptase. J. Clin. Invest. 86: 864-870.

8. Vanderslice, P., S.M. Ballinger, E.K. Tam, S.M. Goldstein, C.S. Craik, and G.H. Caughey. 1990. Human mast cell tryptase: multiple cDNAs and genes reveal a multigene serine protease family. Proc. Natl. Acad. Sci. USA. 87:38113815.

9. Xia, H.-Z., C.L. Kepley, K. Sakai, J. Chelliah, A.-M.A. Irani, and L.B. Schwartz. 1995. Quantitation of tryptase, chymase, FceRI $\alpha$, and FceRIgamma mRNAs in human mast cells and basophils by competitive reverse transcription-polymerase chain reaction. J. Immunol. 154:5472-5480.

10. Schwartz, L.B., K. Sakai, T.R. Bradford, S. Ren, B. Zweiman, A.S. Worobec, and D.D. Metcalfe. 1995. The $\alpha$ form of human tryptase is the predominant type present in blood at baseline in normal subjects, and is elevated in those with systemic mastocytosis. J. Clin. Invest. 95:2702-2710.

11. Neurath, H. 1989. Proteolytic processing and physiological regulation. Trends Biochem. Sci. 14:268-271.

12. McGuire, M.J., P.E. Lipsky, and D.L. Thiele. 1993. Generation of active myeloid and lymphoid granule serine proteases requires processing by the granule thiol protease dipeptidyl peptidase I. J. Biol. Chem. 268:2458-2467.

13. Vanderslice, P., C.S. Craik, J.A. Nadel, and G.H. Caughey. 1989. Molecular cloning of dog mast cell tryptase and a related protease: structural evidence of a unique mode of serine protease activation. Biochemistry. 28:4148-4155.

14. Reynolds, D.S., D.S. Gurley, K.F. Austen, and W.E. Serafin. 1991. Cloning of the cDNA and gene of mouse mast cell protease-6. Transcription by progenitor mast cells and mast cells of the connective tissue subclass. J. Biol. Chem. 266:3847-3853.

15. Murakami, M., S.S. Karnik, and A. Husain. 1995. Human prochymase activation. A novel role for heparin in zymogen processing. J. Biol. Chem. 270: 2218-2223.

16. Dikov, M.M., E.B. Springman, S. Yeola, and W.E. Serafin. 1994. Pro- cessing of procarboxypeptidase A and other zymogens in murine mast cells. $J$. Biol. Chem. 269:25897-25904.

17. Schwartz, L.B., and T.R. Bradford. 1986. Regulation of tryptase from human lung mast cells by heparin. Stabilization of the active tetramer. J. Biol. Chem. 261:7372-7379.

18. Braganza, V.J., and W.H. Simmons. 1991. Tryptase from rat skin: Purification and properties. Biochemistry. 30:4997-5007.

19. Matsumoto, R., A. Sali, N. Ghildyal, M. Karplus, and R.L. Stevens 1995. Packaging of proteases and proteoglycans in the granules of mast cells and other hematopoietic cells. A cluster of histidines on mouse mast cell protease 7 regulates its binding to heparin serglycin proteoglycans. J. Biol. Chem. 270:19524-19531.

20. Sakai, K., S.D. Long, D.A.D. Pettit, G.A. Cabral, and L.B. Schwartz. 1996. Expression and purification of recombinant human tryptase in a baculovirus system. Protein Expr. Purif. 7:67-73.

21. Irani, A.-M.A., T.R. Bradford, C.L. Kepley, N.M. Schechter, and L.B. Schwartz. 1989. Detection of $\mathrm{MC}_{\mathrm{T}}$ and $\mathrm{MC}_{\mathrm{TC}}$ types of human mast cells by immunohistochemistry using new monoclonal anti-tryptase and anti-chymase antibodies. J. Histochem. Cytochem. 37:1509-1515.

22. Butterfield, J.H., D. Weiler, G. Dewald, and G.J. Gleich. 1988. Establishment of an immature mast cell line from a patient with mast cell leukemia. Leuk. Res. 12:345-355.

23. Kishi, K. 1985. A new leukemia cell line with Philadelphia chromosome characterized as basophil precursors. Leuk. Res. 9:381-390.

24. Ziegler-Heitbrock, H.W., E. Thiel, A. Futterer, V. Herzog, A. Wirtz, and G. Riethmuller. 1988. Establishment of a human cell line (Mono Mac 6) with characteristics of mature monocytes. Int. J. Cancer. 41:456-461.

25. Schick, B., K.F. Austen, and L.B. Schwartz. 1984. Activation of rat serosal mast cells by chymase, an endogenous secretory granule protease. J. Immunol. 132:2571-2577.

26. Schwartz, L.B., M.S. Kawahara, T.E. Hugli, D. Vik, D.T. Fearon, and K.F. Austen. 1983. Generation of C3a anaphylatoxin from human C3 by human mast cell tryptase. J. Immunol. 130:1891-1895.

27. Schwartz, L.B., T.R. Bradford, D.C. Lee, and J.F. Chlebowski. 1990. Immunologic and physicochemical evidence for conformational changes occurring on conversion of human mast cell tryptase from active tetramer to inactive monomer: production of monoclonal antibodies recognizing active tryptase. $J$. Immunol. 144:2304-2311.

28. Smith, P.K., R.I. Krohn, G.T. Hermanson, A.K. Mallia, F.H. Gartner, M.D. Provenzano, E.K. Fujimoto, N.M. Goeke, B.J. Olson, and D.C. Klenk. 1985. Measurement of protein using bicinchoninic acid. Anal. Biochem. 150:7685.

29. McGuire, M.J., P.E. Lipsky, and D.L. Thiele. 1992. Purification and characterization of dipeptidyl peptidase I from human spleen. Arch. Biochem. Biophys. 295:280-288.

30. Porter, J.A., D.P. von Kessler, S.C. Ekker, K.E. Young, J.J. Lee, K. Moses, and P.A. Beachy. 1995. The product of hedgehog autoproteolytic cleavage active in local and long-range signalling. Nature (Lond.). 374:363-366.

31. Mach, L., J.S. Mort, and J. Glossl. 1994. Maturation of human procathep$\sin \mathrm{B}$. Proenzyme activation and proteolytic processing of the precursor to the mature proteinase, in vitro, are primarily unimolecular processes. J. Biol. Chem. 269:13030-13035.

32. Alter, S.C., D.D. Metcalfe, T.R. Bradford, and L.B. Schwartz. 1987. Regulation of human mast cell tryptase. Effects of enzyme concentration, ionic strength and the structure and negative charge density of polysaccharides. Biochem. J. 248:821-827.

33. Freer, S.T., J. Kraut, J.D. Robertus, H.T. Wright, and N.H. Xuong 1970. Chymotrypsinogen: 2.5 angstrom crystal structure, comparison with $\alpha$-chymotrypsin, and implications for zymogen activation. Biochemistry. 9:9972009

34. Deyoung, M.B., E.F. Nemeth, and A. Scarpa. 1987. Measurement of the internal $\mathrm{pH}$ of mast cell granules using microvolumetric fluorescence and isotopic techniques. Arch. Biochem. Biophys. 254:222-233.

35. Vertel, B.M., L.M. Walters, N. Flay, A.E. Kearns, and N.B. Schwartz 1993. Xylosylation is an endoplasmic reticulum to Golgi event. J Biol. Chem 268:11105-11112.

36. Calabro, A., and V.C. Hascall. 1994. Differential effects of brefeldin A on chondroitin sulfate and hyaluronan synthesis in rat chondrosarcoma cells. $J$. Biol. Chem. 269:22764-22770.

37. Gullberg, U., A. Lindmark, E. Nilsson, A.-M. Persson, and I. Olsson. 1994. Processing of human cathepsin $\mathrm{G}$ after transfection to the rat basophilic/ mast cell tumor line RBL. J. Biol. Chem. 269:25219-25225.

38. Lindmark, A., U. Gullberg, and I. Olsson. 1994. Processing and intracellular transport of cathepsin $\mathrm{G}$ and neutrophil elastase in the leukemic myeloid cell line U-937-modulation by brefeldin A, ammonium chloride, and monensin. J. Leukoc. Biol. 55:50-57. 